\title{
EFFECT OF A 60-DAY INTERRUPTION DURING THE START-UP PERIOD OF TWO ANAEROBIC BIODIGESTORS TREATING A SLAUGHTERHOUSE EFFLUENT: A HYBRID REACTOR AND A BIOLOGICAL FILTER
}

\section{EFEITO DE UMA PARADA DE 60 DIAS DURANTE O PERÍODO DE PARTIDA DE DOIS BIODIGESTORES ANAERÓBIOS TRATANDO EFLUENTE DE ABATEDOURO: UM REATOR HÍBRIDO E UM FILTRO BIOLÓGICO}

\author{
Ezequiel Nunes ${ }^{1}$, Fábio Piccioni Maioque ${ }^{1}$; \\ Danianni Marinho Zardo ${ }^{1}$; Ana Cláudia Barana ${ }^{{ }^{*}}$ \\ ${ }^{1}$ Engenharia de Alimentos, Universidade Estadual de Ponta Grossa, Ponta Grossa - PR, \\ Brazil. \\ 1*Autor to correspondence: Professora do Departamento de Engenharia de Alimentos, \\ Universidade Estadual de Ponta Grossa, Av.: Carlos Cavalcanti, 4748, CEP 84030-900, \\ Ponta Grossa - PR, Brazil. Tel.: + (55) (42) 3220 3268. Fax: + (55) (42) 32203072. \\ E-mail: acbarana@uepg.br \\ Recebido para publicação em 24/10/2007 \\ Aceito para publicação em 12/03/2008
}

\begin{abstract}
This work aimed at evaluating the effect of a 60-day interruption during the start-up period of two anaerobic biodigestors, a Hybrid Reactor (HR) and a Biological Filter (BF), operating at room temperature while treating a slaughterhouse effluent. The experiment was carried out in the Hydraulic Retention Times (HRT) of ten, eight, and six days. The 60-day interruption took place between eight and sixday HRTs. The Chemical Demand of Oxygen of the affluent of the reactors (CDO) was $3217.3 \mathrm{mgO}$.L-1. The acidity/alkalinity relation of the effluent of the reactors remained constant throughout the experiment, with average parameter values of 0.06 for the HR and BF. The average effluent $\mathrm{pH}$ of the two reactors was 7.59. The COD removal rate of the reactors remained above $89 \%$, with averages of 91.54 and 92.63\% for the Hybrid Reactor and the Biological Filter, respectively. No influence of the 60-day interruption was observed in the start-up of the reactors.
\end{abstract}

Keywords: Anaerobic treatment. Biological filter. Hybrid reactor. Slaughterhouse effluent.

\section{RESUMO}

Este trabalho teve por objetivo, avaliar o efeito de 60 dias de interrupção no período de partida de dois biodigestores anaeróbios, um Reator Híbrido (HR) e um Filtro Biológico (BF), operando à temperatura ambiente, e tratando efluente de aba- 
tedouro. O experimento foi realizado com Tempos de Retenção Hidráulica (TRH), de dez, de oito e de seis dias. A interrupção de 60 dias foi feita entre os TRHs de oito e de seis dias. O afluente dos reatores apresentou Demanda Química de Oxigênio (DQO) de 3217,3 mgO2.L-1. Durante todo o experimento, o efluente dos reatores apresentou relação acidez/alcalinidade praticamente constante, com valores médios de 0,06 para ambos os reatores. A média de $\mathrm{pH}$ dos efluentes dos dois reatores foi de 7,59, tendo a taxa de remoção de DQO dos reatores permanecido sempre acima de $89 \%$, com médias de 91,54 e de 92,63\% para o Reator Híbrido e para o Filtro Biológico, respectivamente. Nas condições estudadas, não se observou influência da parada no período de partida dos reatores.

Palavras-chave: Efluente de abatedouro. Tratamento anaeróbio. Reator híbrido. Filtro biológico.

\section{Introduction}

The disposal and final destination of agroindustries effluents, in big cities, is a problem to be solved. The great variety and amount of chemical compounds in such effluents may cause serious environment damages to aquatic ecosystems (SOUZA et al., 2004).

Brazil has one of the world's largest herds of the main species of animals with commercial value, including bovines, swine, and fowls. This agro industrial complex is quite wide, involving several sources of residues, in practically all the steps, as a consequence of the rearing and the processing of animals (POHLMANN, 2004). Slaughterhouses generate a great volume of residues, and water consumption varies depending on the type of animal and the process used in each industrial plant; the major part is disposed as effluents, with volumes from 1.5 to $2.0 \mathrm{~m}^{3}$ per bovine and 1.0 to $1.5 \mathrm{~m}^{3}$ per swine (POHLMANN, 2004).

The slaughterhouse effluents comprise a mixture of fats, proteins and fibers, resulting in a high content of organic matter and in the residues, partially solubilized, cause a contaminating effect to the rivers and to the sewage system, if not previously treated (CAIXETA et al., 2002; KOBYA et al., 2005; AL-MUTAIRI, 2006). The main characteristics of slaughterhouses wastewater are high organic load, with presence of inorganic nutrients, high alkalinity, relatively high temperature (20 to $30{ }^{\circ} \mathrm{C}$ ) and with absence of toxic compounds (CAMMAROTA; FREIRE, 2006).
Thus, anaerobic systems for the treatment of slaughterhouse effluents have been studied, since they are highly efficient to remove organic load, with significantly low costs, when compared to the aerobic processes. Due to the process efficiency at 20 and $30{ }^{\circ} \mathrm{C}$, anaerobic processes have reached a prominent position, all over the world, mainly, in countries with tropical climate, like Brazil, where environmental conditions are favorable to this kind of process (CHERNICHARO, 1997; TORKIAN et al., 2003; MIRANDA et al., 2005; CHÁVEZ et al., 2005). Anaerobic reactors are high-rate sophisticated systems, which were developed to increase the treatment speed, reducing the area requirements (BARRETO, 2004; MASSÉ; MASSE, 2000; MASSE; MASSÉ, 2005). An important characteristic of high-rate anaerobic processes is their capability of retaining great amounts of biomass, in the system, for long periods of time, even when operating at low hydraulic detention times. In this way, very high cell residence times are provided $\left(\theta_{\mathrm{C}}\right.$ usually over 30 days), favoring to stabilize sludge in the system and consequently, to reduce biomass production coefficient (CHERNICHARO, 1997). Single-phase anaerobic reactors can be used to treat slaughterhouse effluents due to residue's buffering dynamics, which results in the formation of bicarbonates and nitrogen mineralization (TRITT; SCHUCHARDT, 1992; MASSE; MASSÉ, 2005).

In this work, the effect of a 60-day interruption, during the start-up period of two anaerobic biodigestors, a Hybrid Reactor (HR) and a Biological Filter (BF), operating at room temperature and treating slaughterhouse effluent was evaluated. 


\section{Materials and methods}

\section{Reactors}

Two up flow anaerobic reactors, built in PVC (polyvinylchloride), with a diameter of $10 \mathrm{~cm}$ and $30 \mathrm{~cm}$ high, a Hybrid Reactor (HR) and a Biological Filter (BF), both operating at room temperature. The Hybrid Reactor (HR) and Biological Filter (BF) useful volumes were $1.82 \mathrm{~L}$ and $1.56 \mathrm{~L}$ respectively.

The Biological Filter was packed with $0.5 \mathrm{~cm}$ long, $0.5 \mathrm{~cm}$ diameter and $0.1 \mathrm{~cm}$ of wall width polypropylene rings, while the Hybrid Reactor had its top half packed with the same kind of support, in order to provide a UASB reactor at the bottom and a filter at the top (Fig. 1).
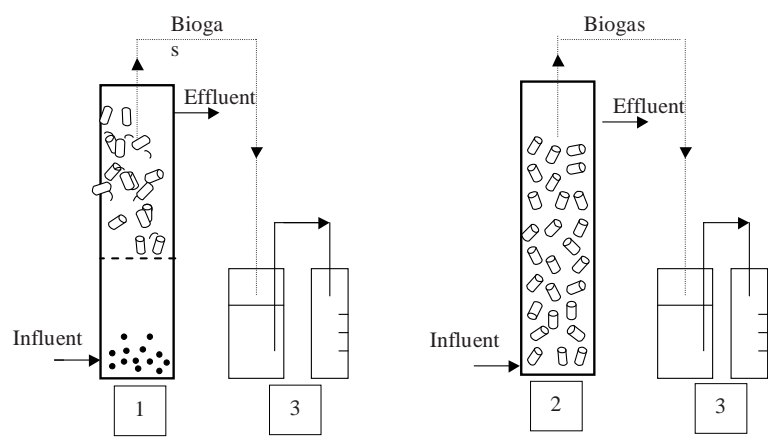

1 - Hybrid Reactor (HR)

2 - Biological Filter (BF)

3- Gasometer

Figure 1 - Schematic representation of the two reactors used

\section{Inoculum}

Both reactors were inoculated with $300 \mathrm{~g}$ sludge from a methanogenic anaerobic reactor, UASB model, operating for ten years at a brewery.

\section{Substrate}

The reactors were fed with the effluent, from a swine and bovine slaughterhouse in Ponta Grossa - PR - Brazil, 2550' South latitude and $50^{\circ} 09^{\prime}$ 'West
Table 1 - Characteristics of the slaughterhouse effluent used in this experiment and effluents used by other authors

\begin{tabular}{|c|c|c|c|c|}
\hline \multirow{2}{*}{ Parameter } & \multicolumn{4}{|c|}{ Concentration } \\
\hline & Experiment & $\begin{array}{l}\text { Cassidy and } \\
\text { Belia (2005) }\end{array}$ & $\begin{array}{c}\text { Masse and Massé } \\
(2005)\end{array}$ & $\begin{array}{l}\text { Merzouk et } \\
\text { al. (2005) }\end{array}$ \\
\hline $\mathrm{pH}$ & 7.68 & 7.30 & 6.85 & 7.29 \\
\hline Alkalinity $\left(\mathrm{mgCaCO}_{3} \cdot \mathrm{L}^{-1}\right)$ & 700 & n.a. & 903 & n.a. \\
\hline $\begin{array}{l}\text { Acidity } \\
\left(\mathrm{mgCH}_{3} \mathrm{COOH}^{-1} \mathrm{~L}^{-1}\right)\end{array}$ & 530 & n.a. & 467 & 117 \\
\hline $\mathrm{COD}\left(\mathrm{mgO}_{2} \cdot \mathrm{L}^{-1}\right)$ & 3217 & 7685 & 7083 & 7780 \\
\hline Nitrogen (mg.L ${ }^{-1}$ ) & 128 & 1057 & 547 & 410 \\
\hline Phosphor (mg.L ${ }^{-1}$ ) & 26 & 217 & n.a. & 18 \\
\hline Total solids (\%) & 0.36 & n.a. & n.a. & n.a. \\
\hline Volatile solids (\%) & 0.54 & n.a. & n.a. & n.a. \\
\hline
\end{tabular}

longitude. The effluent collected after sieving and decantation to the extract the solids, was stored in 5L containers at $-18^{\circ} \mathrm{C}$. The stored effluent was melted and heated to room temperature before feeding the reactors. In Table 1 it is showed the results of the variables used to characterize the effluent, used in this experiment, and of slaughterhouse effluents used by other researchers. It can be observed that there is no homogeneity of results presented by the different authors, once these data vary, according to the process, to the amount of water used, to the number and the size of animals slaughtered, among other factors.

\section{Reactors operation}

The reactors start-up was carried out using the non-diluted effluent with a 10-day HRT, resulting in an organic load of $321 \mathrm{mg}$ COD. $\mathrm{L}^{-1} \cdot \mathrm{d}^{-1}$. After operating for 58 days, in a steady state mode, the HRT employed was eight days, which resulted in a $402 \mathrm{mg}$ COD. $\mathrm{L}^{-1} \cdot \mathrm{d}^{-1}$ organic load. After 55 days with the same HRT the reactors were not fed for 60 days. When the feeding restarted, the HRT used was six days, with the same effluent, for 31 days, resulting in 536 mg COD. $\mathrm{L}^{-1} \cdot \mathrm{d}^{-1}$ organic load.

Both reactors were kept, at room temperature, throughout the whole experiment. The feeding of reactors was carried out, once a day, with enough content to reach the desired HRT. Thus, in order to evaluate the effect of the reactors feeding interruption during the start-up process, analyses of $\mathrm{pH}$, n.a.: not analyzed 
Alkalinity, Acidity, Chemical Oxygen Demand (COD), Nitrogen, Phosphor, Total and Volatile Solids, in the reactors affluent and effluent ones, were carried out. The volume of biogas was quantified through liquid displacement, using gas gasometer, filled with acidified saline solution (25\% w/v de $\mathrm{NaCl}$ e $3 \%$ v/v de $\mathrm{H}_{2} \mathrm{SO}_{4}$ ).

\section{Results and discussion}

In Figure 2, the $\mathrm{pH}$ values, during the experiment are shown, as the average of three results.

The HR effluent $\mathrm{pH}$ value is similar to that of $\mathrm{BF}$, and there was little variation throughout the experiment, both remaining close to neutrality. Even after the restart of the treatment process, on the $173^{\text {rd }}$ day, the variation in $\mathrm{pH}$ values was slight, remaining over 7.40. These results indicate good system buffering and non inhibition of methanogenic archaea at the beginning of the adaptation process.

In Figure 3, the HR and BF effluent acidity/ alkalinity relation values, during the reactors performance monitoring period, are shown.

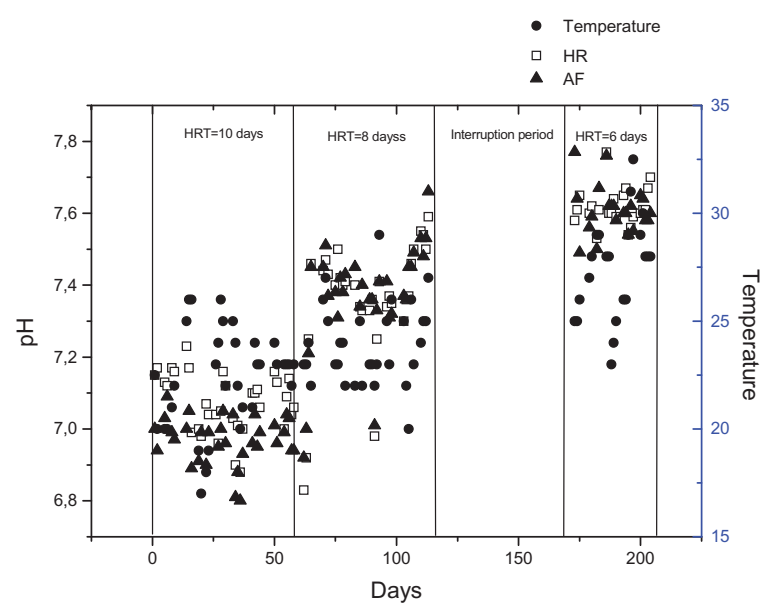

Figure 2 - HR and BF effluent $\mathrm{pH}$ value Graph

The acidity/alkalinity relation values remained below 0.10 most of the time. The high buffering capability, observed for these reactors, results from the formation of bicarbonates and nitrogen mineralization which is favored by the great amount of proteins present in the slaughterhouse effluents (TRITT; SCHUCHARDT, 1992).
During the anaerobic digestion process restart, when the HRT was changed to six days, the acidity/alkalinity did not increase, that is, there was no accumulation of organic acids, in the reactors, indicating non-inhibition of methanogenic archeas by the newly established conditions (Figure 3).

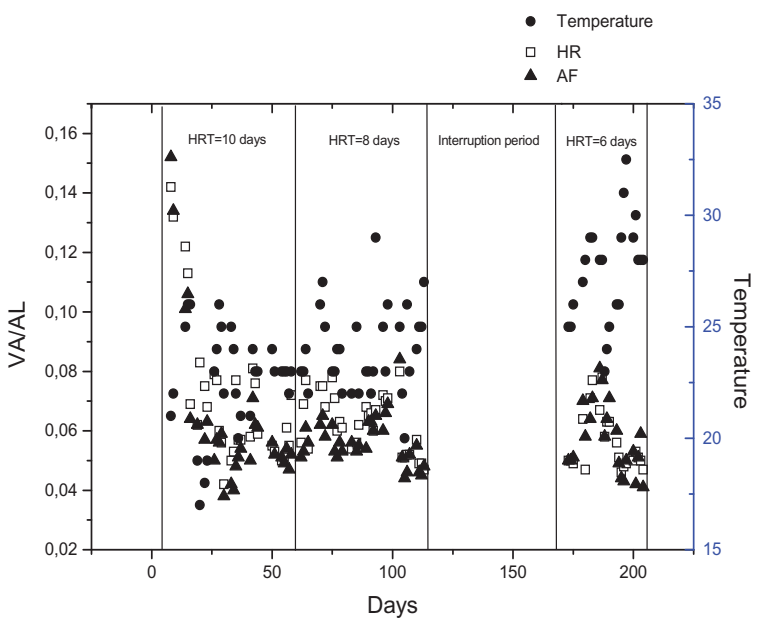

Figure 3 - HR and BF effluent volatily acidity/alkalinity relation values

In Figure 4 data obtained for the performance of HR and BF regarding efficiency in COD removal is presented.

No difference is observed in the COD removal results for both reactors (Figure 4). The low efficiency in removal at the beginning of the process is due to the biomass adaptation the new conditions. From the $20^{\text {th }}$ day on, however, slight variation is

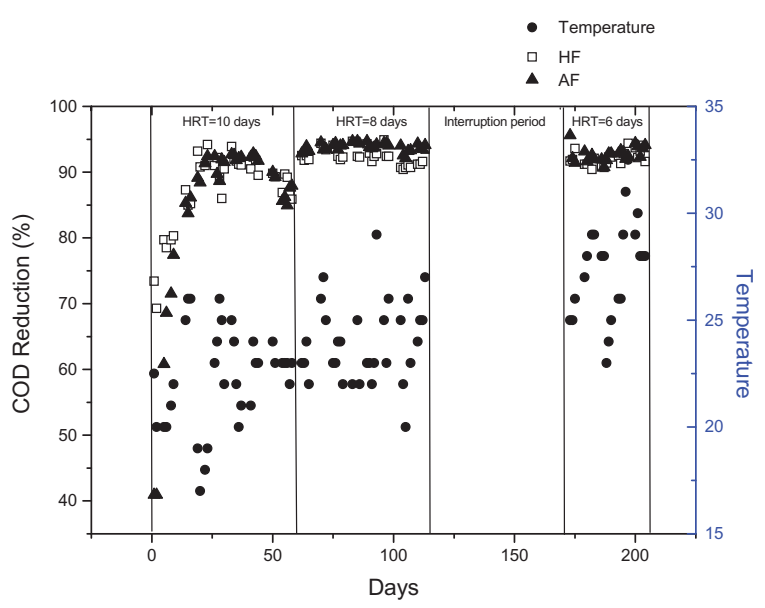

Figure 4 - HR and BF results for COD removal in 8 and 6-day HRTs 
noticed indicating the beginning of the steady state and, consequently, the biomass adaptation. It can be seen that the reactors interruption did not interfere negatively in the reactors start-up process which kept, with HRT of 6 days, COD removal indexes above $90 \%$.

Room temperature remained above $20^{\circ} \mathrm{C}$, throughout the whole experiment, with $26^{\circ} \mathrm{C}$ average, that probably, might have favored the anaerobic digestion process stability, resulting in the reactors high efficiency in what concerns the removal of organic matter.

The average values of parameters used to evaluate the reactors performance in the HRT of 8 and 6 days are in Table 2.

The biogas production, observed during the experiment, was also an indicative of the high efficiency of the process. In Table 2, it is shown that and / or its conversion into biomass. Polprasert et al. (1992), studying slaughterhouse effluent anaerobic treatment, observed concentration of nitrogen, in the biogas, from 20 up to $27 \%$.

\section{Conclusion}

Stable conditions predominated, in both HR and BF reactors, throughout the whole experiment. The $\mathrm{pH}$ value was close to neutrality, and the rising, in alkalinity, allowed occurs. Even when HRT decrease, during the reactors operation restart, no reduction of $\mathrm{pH}$ or increase, in acidity, was observed.

The reactors efficiency, regarding organic matter removal, remained high throughout the experimental period. The HR and BF efficiencies, in

Table 2 - Average values of parameter, analyzed for HR and BF effluents in the HRTs of 10, the removal of organic 8 and 6 days (standard deviations are presented in parenthesis)

\begin{tabular}{|c|c|c|c|c|c|c|}
\hline \multirow[t]{2}{*}{ Parameter } & \multicolumn{2}{|c|}{ HRT 10 days } & \multicolumn{2}{|c|}{ HRT 8 days } & \multicolumn{2}{|c|}{ HRT 6 days } \\
\hline & HR & $\mathrm{BF}$ & HR & $\mathrm{BF}$ & $\mathrm{HR}$ & $\mathrm{BF}$ \\
\hline & 7.06 & 6.97 & 7.54 & 7.57 & 7.62 & 7.60 \\
\hline $\mathrm{PH}$ & $(0.08)$ & $(0.06)$ & $(0.17)$ & $(0.17)$ & $(0.06)$ & $(0.06)$ \\
\hline Alkalinity (mg CaCO$\left.{ }_{3} \cdot \mathrm{L}^{-1}\right)$ & $\begin{array}{c}979.52 \\
(150.62)\end{array}$ & $\begin{array}{c}986.84 \\
(156.73)\end{array}$ & $\begin{array}{l}1296.15 \\
(35.05)\end{array}$ & $\begin{array}{l}1326.92 \\
(33.02)\end{array}$ & $\begin{array}{c}1405.86 \\
(83.72)\end{array}$ & $\begin{array}{c}1412.73 \\
(77.61)\end{array}$ \\
\hline Acidity (mg CH $\left.\mathrm{COOH}_{3} \mathrm{~L}^{-1}\right)$ & $\begin{array}{c}73.81 \\
(23.63)\end{array}$ & $\begin{array}{c}64.80 \\
(12.46)\end{array}$ & $\begin{array}{c}81.69 \\
(10.67)\end{array}$ & $\begin{array}{l}73.54 \\
(5.31)\end{array}$ & $\begin{array}{c}82.69 \\
(17.91)\end{array}$ & $\begin{array}{c}80.61 \\
(17.96)\end{array}$ \\
\hline Acidity/alkalinity relation & 0.07 & 0.06 & 0.06 & 0.06 & 0.06 & 0.06 \\
\hline $\mathrm{COD}\left(\mathrm{mgO}_{2} \cdot \mathrm{L}^{-1}\right)$ & $\begin{array}{l}214.27 \\
(97.01)\end{array}$ & $\begin{array}{c}274.04 \\
(226.70)\end{array}$ & $\begin{array}{l}243.97 \\
(37.21)\end{array}$ & $\begin{array}{l}202.95 \\
(20.88)\end{array}$ & $\begin{array}{l}247.05 \\
(36.83)\end{array}$ & $\begin{array}{l}232.04 \\
(36.07)\end{array}$ \\
\hline Nitrogen (mg. $\left.\mathrm{L}^{-1}\right)$ & n.a. & n.a. & 53.68 & 43.43 & 44.88 & 47.66 \\
\hline Phosphor (mg. $\left.\mathrm{L}^{-1}\right)$ & n.a. & n.a. & 30.21 & 30.00 & 40.74 & 35.17 \\
\hline Total Solids (\%) & n.a. & n.a. & 0.19 & 0.19 & 0.19 & 0.19 \\
\hline Volatile Solids (\%) & n.a. & n.a. & 0.14 & 0.14 & 0.14 & 0.14 \\
\hline $\operatorname{Biogas}\left({\left.\mathrm{L} . \mathrm{d}^{-1}\right)}\right.$ & n.a. & n.a. & 0.23 & 0.25 & 0.30 & 0.33 \\
\hline
\end{tabular}
matter, were similar, indicating that, under the conditions of this experiment, both reactors have shown similar behavior.

n.a.: not analyzed

the biogas production volume increased, when the HRT was changed from eight to six days, following the increase in organic load.

According to data in Table 2, it can be noted that the values for the reactors effluent, Total and Volatile Solids, was the same for both HRTs employed. Nitrogen removal can also be seen, which could be explained by the loss of gaseous nitrogen

\section{REFERENCES}

AL-MUTAIRI, N. Z. Coagulant toxicity and effectiveness in a slaughterhouse wastewater treatment plant, Ecotoxicology and Environmental Safety, v. 65, p.74-83, 2006.

BARRETO, C. O. Tratamento de efluentes na indústria frigorífica - Parte 3, Revista Nacional da Carne, n. 327, p.138-141, 2004. 
CAIXETA, C. E. T.; CAMMAROTA, M. C.; XAVIER, A. M. F. Slaughterhouse wastewater treatment: evaluation of a new three-phase separation system in an UASB reactor, Bioresource Technology, v. 81, p. 61-69, 2002.

CAMMAROTA, M. V.; FREIRE, D. M. G. A review on hydrolytic enzymes in the treatment of wastewater with high oil and grease content, Bioresource Technology, v. 97, p.2195-2210, 2006.

CASSIDY, D. P.; BELIA, E. Nitrogen and phosphorous removal from an abattoir wastewater in a SBR with aerobic granular sludge, Water research, v. 39, p. 4817- 4823, 2005.

CHÁVEZ P. C. et. al. Poultry slaughter wastewater treatment with an up-flow anaerobic sludge blanket (UASB) reactor, Bioresource Technology, v. 96, n. 15, p. 1730-173, 2005.

CHERNICHARO, C. A. L., Reatores anaeróbios. Série: Princípios do tratamento biológico de águas residuárias. v. 5. Belo Horizonte: Departamento de Engenharia Sanitária e Ambiental - UFMG, 1997. 245p.

KOBYA, M.; SENTURK, E.; BAYRAMOGLU, M. Treatment of poultry slaughterhouse wastewaters by eletrocoagulation, Journal of Hazardous Materials, v. 133, n. 1-3, p.172-176, 2005.

MASSÉ, L.; MASSE, D. I. Effect of soluble organic, particulate organic, and hydraulic shock loads on anaerobic sequencing batch reactors treating slaughterhouse wastewater at $20^{\circ} \mathrm{C}$, Process Biochemistry, v. 40, n. 3-4, p.1225-1232, 2005.

MASSÉ, D. I.; MASSE, L., Characterization of wastewaters from hog slaughterhouses in Eastern Canada and evaluation of their in-plant wastewater treatment systems, Canadian Agricultural Engineering, v. 42, n. 3, p. 139-146, 2000.

MERZOUK, M. et. al. Effect of prefermentation on denitrifying phosphorous removal in slaughterhouse wastewater, Bioresource Technology, v. 96, p. 1317-1322, 2005.

MIRANDA, L. A. S.; HENRIQUES, J. A. P.; MONTEGGIA, L. O. A full-scale UASB reactor for treatment of pig and cattle slaughterhouse wastewater with a high oil and grease content, Brazilian Journal of Chemical Engineering, v. 22, n. 4, p. 601-610, 2005.

POHLMANN, M., Tratamento de efluentes na indústria frigorífica - Parte 1. Revista da Carne, n. 325, p. 94-98, 2004.

POLPRASERT, C.; KEMMADAMRONG, P.; TRAN, F. Anaerobic baffled reactor (ABR) process for treating a slaughterhouse wastewater, Environmental Technology, v. 13, p. 857-865, 1992.

SOUZA, R. R. et. al. The performance of a three-phase fluidized bed reactor in treatment of wastewater with high organic load, Brazilian Journal of Chemical Engineering, v. 21, n. 2, p. 219-227, 2004.

TORKIAN, A.; EQBALI, A.; HASHEMIAN, S. J., The effect of organic loading rate on the performance of UASB reactor treating slaughterhouse effluent, Resources, Conservation and Recycling, v.40, n.1, p.1-11, 2003.

TRITT, W. P.; SCHUCHARDT, F., Materials flow and possibilities of treating liquid and solid wastes from slaughterhouse in Germany. A review, Bioresource Technology, v. 41, p. 235-245, 1992. 